IIIIIIIIIIIIIIIIIIIIIIIIIII!

\title{
畑土壤中のクロロタロニル消失過程における炭素同位体分別
}

\author{
山本 幸 洋*, 田 中 福 代', 藤 原 伸 介†, 松丸 恒 夫 \\ 千葉県農業総合研究センター, †独立行政法人農業技術研究機構中央農業総合研究セン夕ー
}

（平成 15 年 4 月 7 日受付，平成 15 年 9 月 11 日受理）

\section{Carbon Isotope Fractionation during Chlorothalonil Dissipation in an Upland Soil}

\author{
Yukihiro YAmAmoto, ${ }^{*}$ Fukuyo TANAKA, ${ }^{\dagger}$ Shinsuke FujIHARA ${ }^{\dagger}$ and Tsuneo MATSUMARU \\ Chiba Prefectural Agriculture Research Center, 808 Daizenno-cho, Midori-ku, Chiba 266-0006, Japan \\ ${ }^{\dagger}$ National Agricultural Research Center, 3-1-1 Kannondai, Tsukuba, Ibaraki 305-8666, Japan
}

\begin{abstract}
We investigated changes in the $\delta^{13} \mathrm{C}$ value of a pesticide during its dissipation in an upland soil. Chlorothalonil (2,4,5,6-tetrachloro-1,3-isophthalonitrile) as a test chemical was added to the soil (Light-colored Andosol) and incubated at $30^{\circ} \mathrm{C}$ in the dark. The pesticide was periodically extracted from the soil and subjected to analysis with an isotope ratio mass spectrometer. The $\delta^{13} \mathrm{C}$ value of chlorothalonil in the soil increased from -26.5 to $-22.5 \%$ during the incubation period of 70 days. The enrichment factor in this study was $-2.6 \%$. These results suggest the occurrence of carbon isotope fractionation during the dissipation of chlorothalonil in the soil environment.
\end{abstract}

Keywords: isotope fractionation, stable isotope, $\delta^{13} \mathrm{C}$, chlorothalonil, enrichment factor, gas chromatograph/ combustion/isotope ratio mass spectrometry (GC/C/IRMS).

\section{緒 言}

農薬は, 安定した農業生産を維持する上で必要不可欠な 資材である. しかし，農薬はほ場という開放系で使用され る化学物質であるため, 環境中に放出され, 水や大気, 土 壤を介して人体や非標的生物に影響を及ぼすことが懸念さ れる. 特に, 近年では複数の農薬が「内分泌攪乱作用を有 すると疑われる化学物質」としてリストアップされ1), 社 会的にも農薬の環境中における動態に対して関心が高まっ ている，今後，環境中に放出された農薬の安全性を評価す るためには，その動態をより詳細に解明する必要がある.

一般に, 環境中における農薬の消失過程には, 蒸発, 流 亡, 分解等, 複数の要因が関与する ${ }^{2)}$.このような複数の 要因が関与する現象において, 特定の要因の寄与を推定す る方法の一つが, 物質の反応過程における安定同位体自然 存在比の変化, すなわち, 同位体分別を利用する方法であ る. この方法は, 同位体分別の程度を表す濃縮係数 (en-

\footnotetext{
* To whom correspondence should be addressed.
}

richment factor）を用いて, 同位体分別を伴う要因の寄与 を推定する゙). しかし, 現在までに, 環境中における農薬 の消失過程において同位体分別は確認されておらず，した がって, 濃縮係数も明らかにされていない。

そこで, 本研究では, 畑土㙵中のクロロタロニル消失過 程における炭素同位体分別の存在を確認する.

\section{材料および方法}

供試薬剤は，クロロタロニル（2,4,5,6-tetrachloro-1,3-isophthalonitrile, 和光純薬社製, 残留農薬試験用, 純度 99.0 $\%$ 以上）とし, 珪藻土（Varian 社製 Chem TubeHydromatrix）とと屯に粉砕混合して $1 \%(\mathrm{w} / \mathrm{w})$ の粉剤と したあのを用いた，供試土壌は，淡色黒ボク土（大川口統, 土性 : $\mathrm{CL}, \mathrm{pH}\left(\mathrm{H}_{2} \mathrm{O}\right): 5.39$, 有機炭素含量 : $5.3 \%$, 採取 地：茨城県つくば市観音台）とし，2 mm の篩を通したも のを用いた。

乾土 $10 \mathrm{~g}$ 相当の供試土壤を $100 \mathrm{ml}$ 容ビーカーにとり, 供試薬剤を有効成分で $0.5 \mathrm{mg}$ 添加後混合した。この添加 
量は, クロロタロニル $10 \%$ 粉剤（商品名：ダコソイル） の散布量 $(40 \mathrm{~kg} / 10 \mathrm{a})$ を想定している.さらに, 蒸留水 を添加して土壌の水分条件を最大容水量の $60 \%$ に調整し, 慣行施肥窒素量に相当する硫酸アンモニウム $9.43 \mathrm{mg}$ を添 加後混合した.アルミ箔で軽くふたをして暗黒条件下, $30^{\circ} \mathrm{C}$ 恒温器内で培養した。培養期間は, 培養開始から 0 , $7 ， 21 ， 35 ， 49 ， 70$ 日とした。培養中の土壤含水量は, 試 料の全重量を週 2 回測定して把握し, 蒸発による減少量を 補充した。試験はすべて 3 反復で行った。

培養後の土壌からクロロタロニルを回収する方法は, 操 作中に炭素同位体分別が生じることを回避するため, 以下 のように従来法 ${ }^{4)}$ と比べて工程数を減らしたものとした. 試料 $1 \mathrm{~g}$ と珪藻土 $0.2 \mathrm{~g}$ （Varian 社製 Chem TubeHydromatrix）を $10 \mathrm{ml}$ 容稀じ口付き試験管にとり, 酢酸エ チル $5 \mathrm{ml}$ で 2 回振とう抽出し, 無水硫酸ナトリウムを少 量加えたろ紙を用いて脱水, 万過後, 減圧濃縮して酢酸工 チルで $1 \mathrm{ml}$ に定容した. 定量には, ガスクロマトグラフ 質量分析計（GC/MS，ヒューレットパッカード社製 HP5971, 分離カラム Ultra ALLOY-5）を用いた。添加回収率 は $50 \mathrm{ppm}$ 添加相当で $47 \%, 10 \mathrm{ppm}$ 添加相当で $42 \%, 2$ $\mathrm{ppm}$ 添加相当で $50 \%$ あった．定量值は， $50 \mathrm{ppm}$ 添加相 当の回収率で補正した，GC/MSによる定量後, 抽出液を クロロタロニル濃度が約 30 $50 \mathrm{mg} / 1$ となるまで窒素気流 下で濃縮し，炭素安定同位体の分析に供した。炭素安定同 位体自然存在比の分析には，ガスクロマトグラフ／燃焼／ 安定同位体比質量分析計 (GC/C/IRMS, サーモ・フィニ ガン社製 DELTA plus）を用いた。分析条件は Table 1 に 示した。炭素安定同位体自然存在比は，(1)式による ${ }^{13} \mathrm{C}$ 值で示した（単位はパーミル，\%)。

$$
\delta^{13} \mathrm{C}(\%)=\left(R_{\text {sample }} / R_{\text {standard }}-1\right) \times 1000
$$

Table 1. Analytical conditions of GC/C/IRMS to measure carbon isotope ratios of chlorothalonil

\begin{tabular}{|c|c|}
\hline $\begin{array}{l}\text { Isotope ratio mass } \\
\text { spectrometer }\end{array}$ & $\begin{array}{l}\text { Thermo Finnigan DELTA plus } \\
\text { equipped with gas chromatograph } \\
\text { Agilent Technologies } 6890\end{array}$ \\
\hline Injection volume & $4 \mu 1$ \\
\hline Carrier gas & $\mathrm{He}$ \\
\hline Inlet & $\begin{array}{l}250^{\circ} \mathrm{C} \text {, Splitless, } 1.5 \mathrm{ml} / \mathrm{min} \text { constant } \\
\text { flow }\end{array}$ \\
\hline Column & $\begin{array}{l}\text { HP-5, I.D. } 0.32 \mathrm{~mm} \text {, length } 30 \mathrm{~m} \text {, film } \\
\text { thickness } 0.25 \mu \mathrm{m}\end{array}$ \\
\hline Oven temperature & $\begin{array}{l}50^{\circ} \mathrm{C}(1 \mathrm{~min})-20^{\circ} \mathrm{C} / \mathrm{min}^{-}-250^{\circ} \mathrm{C} \\
(5 \mathrm{~min})\end{array}$ \\
\hline Retention time & $692 \mathrm{sec}$ \\
\hline $\begin{array}{l}\text { Combustion reactor tem- } \\
\text { perature }\end{array}$ & $850^{\circ} \mathrm{C}$ \\
\hline $\begin{array}{l}\text { Reduction reactor tem- } \\
\text { perature }\end{array}$ & $650^{\circ} \mathrm{C}$ \\
\hline
\end{tabular}

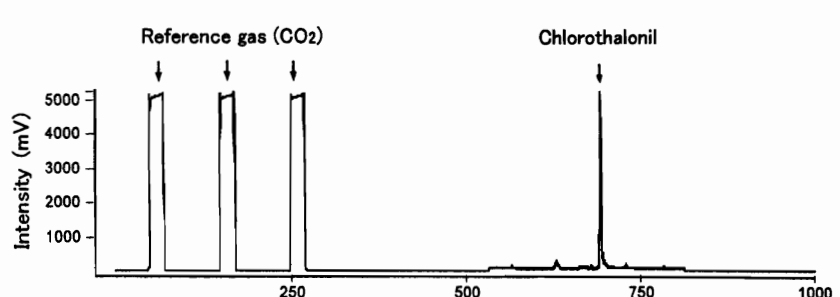

(a)

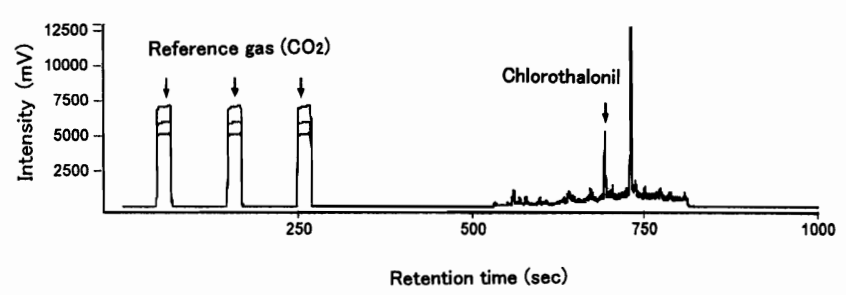

(b)

Fig. 1. GC/C/IRMS chromatograms of chlorothalonil. (a) Standard (50 mg/l), (b) Sample (incubation period was 70 days).

ここで $R_{\text {sample }}$ と $R_{\text {standard }}$ はそれぞれ試料と標準物質の ${ }^{13} \mathrm{C} /{ }^{12} \mathrm{C}$ 比を示し，標準物質にはPDB（アメリカ白亜紀 Pee Dee 層の巻貝化石である Beleminite, $\left.\mathrm{CaCO}_{3},{ }^{13} \mathrm{C} /{ }^{12} \mathrm{C}=0.01124\right)$ を用いた ${ }^{5)} . \mathrm{GC} / \mathrm{C} / \mathrm{IRMS}$ は, 測定ごとに $\delta^{13} \mathrm{C}$ 值が既知の $\mathrm{CO}_{2}$ で補正した。 GC/C/IRMS の分析精度は, クロロ夕ロ ニル標準品の $\delta^{13} \mathrm{C}$ 值の変動係数で $1.9 \%$ あった。 土壌に 添加前と添加直後のクロロタロニルの $\delta^{13} \mathrm{C}$ 値は, それぞ

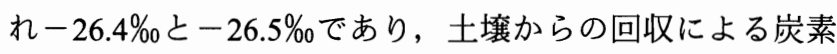
同位体分別は無視できると考えられる.

\section{結果および考察}

GC/C/IRMS によるクロロタロニルの分析例を Fig. 1 に 示した.（a）は標準試薬（50 mg/l）であり，（b）は培養期 間 70 日の試料である. クロロタロニルのピークは, 土壌 由来の他のピークから十分に分離していた.

土壤中におけるクロロタロニルの濃度推移を Fig. 2 .上段 に示した，クロロタロニルの濃度は, 培養期間が長くなる ほど低下し，その半減期( ロニルの土㙵中半減期は 5 36 日といわれており7), 本研 究における結果むその範囲内にあった。

土壌中におけるクロロタロニルの $\delta^{13} \mathrm{C}$ 值の推移を Fig. 2 下段に示した. クロロタロニルの $\delta^{13} \mathrm{C}$ 值は, 培養開始時で はー26.5\% であったが経時的に高くなり，培養期間 70 日 では一 $22.5 \%$ まで上昇した。すなわち，土黈中に残存する クロロタロニル中の炭素は, 消失したクロロタロニル中の 炭素と比べて ${ }^{13} \mathrm{C}$ の比率が高くなった。 3 連の培養処理間 における $\delta^{13} \mathrm{C}$ 值の標準偏差は，培養期間が長くなるほど大 きくなったが，培養開始時と培養期間 21 日以降の $\delta^{13} \mathrm{C}$ 值 

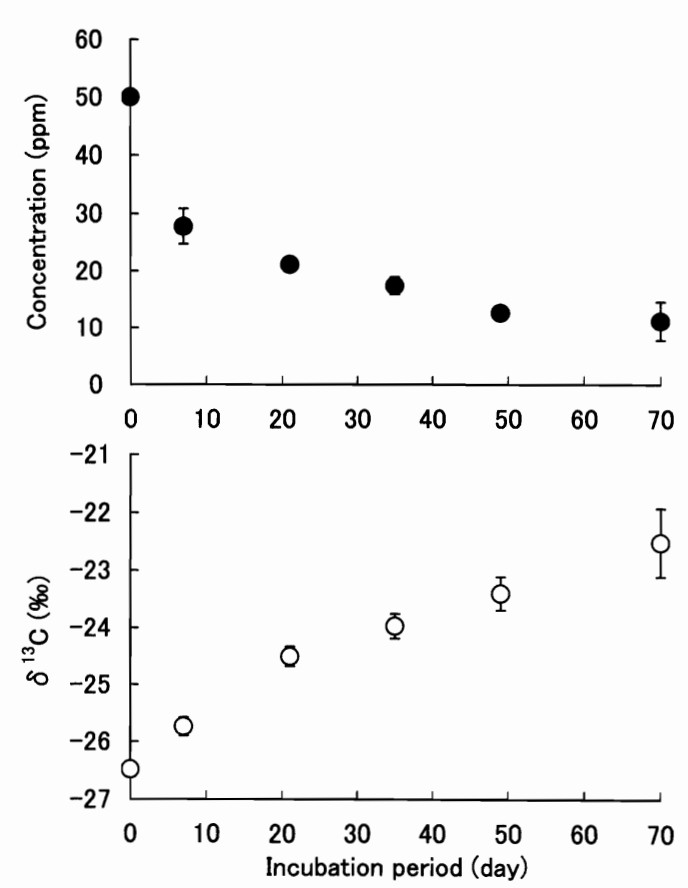

Fig. 2. Concentration and $\delta^{13} \mathrm{C}$ value of chlorothalonil in upland soil.

* Bar: \pm standard deviation.

は有意に差があった（Scheffe's F 検定, 危険率 1\%). 以上 のことから, 畑土壌におけるクロロ夕ロニルの消失過程に おいて炭素同位体分別が生じていると考えられた。

他の有機塩素化合物のテトラクロロエチレンやトリクロ ロエチレンでは, 微生物による脱塩素の過程で炭素同位体 分別が生じることが知られている ${ }^{8,9)}$. 畑土壤におけるク ロロタロニルが消失する要因の一つが微生物による分解で あり ${ }^{10)}$ ，代謝産物として 1 塩素が $\mathrm{OH}$ 基に置換した 4hydroxy-2,5,6-trichloroisophthalonitrile 等が生成する ${ }^{11,12}$. こ れらのことから, 本研究における炭素同位体分別は, ク口 ロタロニルの微生物分解により生じた可能性がある。炭素 同位体分別が生じるメカニズムとしては, クロロタロニル の消失に関与する部位における ${ }^{13} \mathrm{C}$ の結合力が, ${ }^{12} \mathrm{C}$ と比べ て強いことが考えられる ${ }^{8}$.

本研究における炭素同位体分別の程度を評価するため, 濃縮係数 $\varepsilon$ を Mariotti らにより導かれた，いわゆる Rayleigh の式により求めた ${ }^{3,13,14)}$.

$$
\delta_{s}=\delta_{s_{0}}+\varepsilon \ln C / C_{0}
$$

ここで

$\delta_{s}:$ 試料の $\delta^{13} \mathrm{C}$ 值 $(\% 0)$

$\delta_{s_{0}}:$ 測定開始時の試料の $\delta^{13} \mathrm{C}$ 値 $(\% 0)$

$C:$ 試料のクロロタロニル濃度 $(\mathrm{ppm})$

$C_{0}:$ 測定開始時の試料のクロロタロニル濃度 $(\mathrm{ppm})$

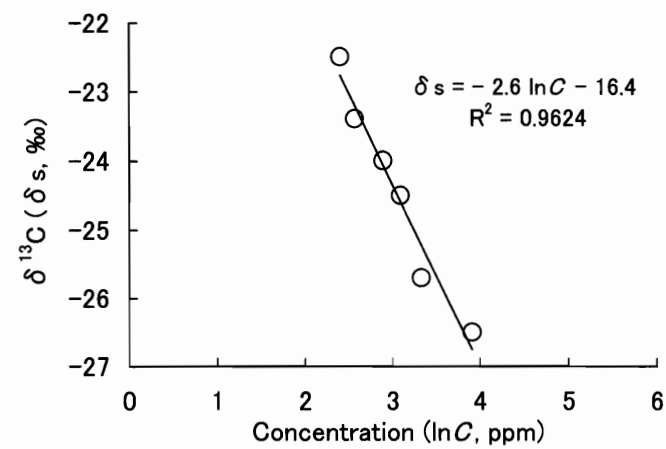

Fig. 3. Relationship between concentration $(\ln C)$ and $\delta^{13} \mathrm{C}$ value of chlorothalonil in upland soil.

$$
\begin{gathered}
a=\delta_{s_{0}}-\varepsilon \ln C_{0} \text { とすると（2)式より， } \\
\delta_{s}=a+\varepsilon \ln C
\end{gathered}
$$

ただし， $a, \varepsilon$ は定数である.

本研究における結果を（3)式に当てはめると次の回帰直 線が得られる (Fig. 3).

$$
\delta_{\mathrm{s}}=-16.4-2.6 \ln C \quad R^{2}=0.9624
$$

よって, 濃縮係数 $\varepsilon$ は $-2.6 \%$ と推定される。この值は, Bloom らが求めたトリクロロエチレンの脱塩素過程におけ る濃縮係数 $-2.5 \%$ と同等であった9).

さらに，炭素同位体分別の利用例を以下に示す。ここで は, 本研究におけるクロロタロニルの消失と炭素同位体分 別が, あるA という要因でのみ生じたと仮定する, 上記 の濃縮係数 $\varepsilon$ を(2)式に当てはめると,

$$
\delta_{s}=\delta_{s_{0}}-2.6 \ln C / C_{0}
$$

となる，すなわち, 濃度 $C_{1}$ から $C_{2}$ までのクロロタロニル 消失による $\delta^{13} \mathrm{C}$ 值の変化を $\Delta \delta^{13} \mathrm{C}$ 值とすると,

$$
\begin{aligned}
\Delta \delta^{13} \mathrm{C}(\% 0) & =\delta^{13} \mathrm{C}_{2}-\delta^{13} \mathrm{C}_{1} \\
& =2.6 \ln C_{2} / C_{1}
\end{aligned}
$$

となる．環境中におけるクロロタロニルの消失に要因 A と他の炭素同位体分別を伴わない要因が関与した場合, こ の式と $\delta^{13} \mathrm{C}$ 值の差（ $\left.\Delta \delta^{13} \mathrm{C}\right)$ から要因 $\mathrm{A}$ による消失量のみ を推定できる3).

本研究により, 畑土壌におけるクロロタロニルの消失過 程において炭素同位体分別が生じていることが確認された。 今後, 同位体分別という現象を環境中における農薬の動態 研究に利用するため, 各種農薬の消失要因と同位体分別之 の関係を明らかにする必要がある。

$$
\text { 要 約 }
$$

環境中の農薬の炭素同位体分別の存在を確認するため, 
畑土袞における農薬の炭素安定同位体自然存在比の経時変 化を測定した。供試薬剤のクロロタロニル（2,4,5,6tetrachloro-1,3-isophthalonitrile) を淡色黒ボク土に添加（0.5 $\mathrm{mg} / 10 \mathrm{~g}$ ）し，暗黒条件下， $30^{\circ} \mathrm{C}$ で 70 日間培養した。ク口 ロタロニルの $\delta^{13} \mathrm{C}$ 值は，培養期間中に $-26.5 \%$ から -22.5 \%。まで上昇した。このときの濃縮係数は， $-2.6 \%$ であっ た. 以上から，畑土壌における本薬剤の消失過程において 炭素同位体分別が生じていることが確認された。

本研究を実施するにあたり, 独立行政法人農業技術研究機構 中央農業総合研究センター土壌肥料部, ならびに千葉県農業総 合研究センター生産環境部の各位に多大なるご協力を賜った. また, 東京大学農学生命科学研究科米山忠克教授にご校閲を睗っ た.ここに記して深く感謝の意を表する.

\section{引 用 文 献}

1）環境庁：内分泌攪乱化学物質問題への環境庁の対応方針に ついて一環境ホルモン戦略計画 SPPEED’98-, 2000 年 11 月版, 35-36 (2000).
2）金澤 純：農薬の環境科学, 合同出版, pp. 93-97, 1992.

3）朴 光来, 山本洋司, 中西康博, 熊澤喜久雄 : 土肥誌 67 , 314-316 (1996).

4）上路雅子, 小林裕子, 中村幸二：2002 年版残留農薬分析 法, ソフトサイエンス社, pp. 112-113, 2001.

5）米山忠克：土肥誌 58，252-268 (1987).

6）丸 諭: 千葉農試特報 18，27-33 (1991).

7) "The Pesticide Manual," ed. by C. D. S. Tomlin, 12th Ed., British Crop Protection Council, Surrey, pp. 168-169, 2000.

8) D. Hunkeler, R. Aravena and B. J. Butler: Environ. Sci. Technol. 33, 2733-2738 (1999).

9) Y. Bloom, R. Aravena, D. Hunkeler, E. Edwards and S. K. Frape: Environ. Sci. Technol. 34, 2768-2772 (2000).

10) A. Katayama, H. Isemura and S. Kuwatsuka: J. Pestic. Sci. 16, 233-238 (1991).

11) K. Motonaga, K. Takagi and S. Matsumoto: Environ. Toxicol. Chem. 17, 1469-1472 (1998).

12）片山新太：農薬誌 25, 300-309 (2000).

13) A. Mariotti, J. C. Germon, P. Hubert, P. Kaiser, R. Letolle, A. Tardieux and P. Tardieux: Plant Soil 62, 413-430 (1981).

14) A. Mariotti, A. Landreau and B. Simon: Geochim. Cosmochim. Acta 52, 1869-1878 (1988). 